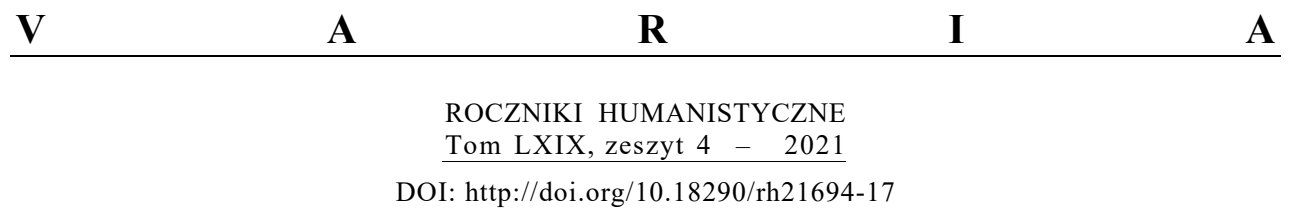

ANNA GLOWA

\title{
ZASŁONY \\ W KOŚCIOŁACH WCZESNOCHRZEŚCIJAŃSKICH W IV-VI WIEKU - ZARYS PROBLEMATYKI
}

Wnętrza wczesnochrześcijańskich kościołów kojarzą się nam na ogół z barwnymi mozaikami i okładzinami z kolorowych marmurów, ewentualnie srebrnymi i złotymi elementami wyposażenia. Tymczasem owe kościoły były pełne również, o czym rzadko się wspomina, różnego rodzaju tkanin: obrusów i elementów bielizny kielichowej, poduszek, tkanin ściennych i zasłon umieszczanych w różnych miejscach w obrębie budowli. Wszystkie te zasłony pełniły funkcje praktyczne, symboliczne i - last but not least dekoracyjne. Wydaje się, że na szczególną uwagę spośród wymienionych tkanin zasługują właśnie zasłony (łac vela, gr. $\beta \tilde{\eta} \lambda \alpha$ ). Celem niniejszego artykułu jest pokazanie, jak ważne miejsce zajmowały one w użytkowaniu budowli kościelnej i jej percepcji już w najwcześniejszym okresie rozwoju architektury chrześcijańskiej, w okresie od IV do VI wieku.

\section{MIEJSCE I FUNKCJA ZASŁON \\ W KOŚCIOŁACH WCZESNOCHRZEŚCIJAŃSKICH W ŚWIETLE ŹRÓDEŁ}

Na wstępie trzeba podkreślić, że zastosowanie zasłon w kościołach było pod wieloma względami analogiczne jak w innych późnoantycznych budowlach.

Dr AnNa GŁowa - Katolicki Uniwersytet Lubelski Jana Pawła II, Wydział Nauk Humanistycznych, Instytut Nauk o Sztuce, Katedra Badań nad Sztuką od Starożytności do Współczesności; adres do korespondencji: Aleje Racławickie 14, 20-950 Lublin; e-mail: annaglowa@, kul.pl; ORCID: https://orcid.org/0000-0002-0478-7563. 
W domach, pałacach, bazylikach świeckich, świątyniach pogańskich vela umieszczano przede wszystkim $\mathrm{w}$ drzwiach wejściowych i pomiędzy pomieszczeniami wewnątrz budynku, w interkolumniach portyków (np. w perystylach), w absydach bazylik pałacowych i foralnych (W. Smith 1028; Ripoll; Stephenson). Jak twierdzą badacze późnoantycznej architektury, „draperies were no substitute, no mere convenient alternative to walls and doors, but key elements of architectural design" (Thébert 389), jednocześnie będąc nośnikami symbolicznych znaczeń na płaszczyźnie politycznej, społecznej i religijnej (Stephenson 3).

Tak jak w domach i pałacach, również w kościołach podstawowym miejscem, w którym wieszano zasłony, były drzwi wejściowe. To o nich najczęściej wspominają źródła pisane. Datowany na przełom V/VI wieku inwentarz kościoła we wsi Ibion w Egipcie (P. Grenf. II, 111, wyd. Hunt i Grenfell

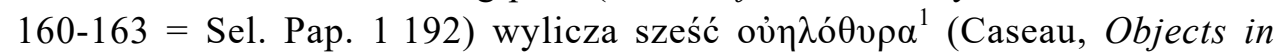
Churches 562-563). Chronicon Paschale, dokument powstały co prawda dopiero w 1. połowie VII stulecia, lecz opierający się na wcześniejszych

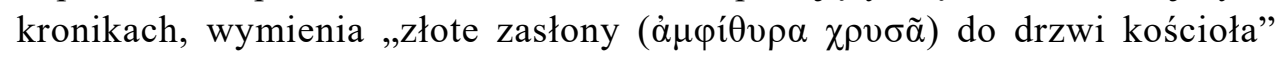
wśród darów Konstancjusza II (337-361) dla Hagia Sophia w Konstantynopolu (Chronicon Paschale I, 544 - ed. Dindorf 544). O zasłonach w drzwich (vela ad ostia) wspomina również kanon 13 synodu w Narbonne w 589 r. (Acta Synodalia 211), który zaleca ostiariuszom ich podnoszenie w momencie przechodzenia starszych (wyższych rangą duchownych). Warto wspomnieć, że podobny zwyczaj istniał w sferze świeckiej. W domach możnych $\mathrm{i}$ w pałacach cesarskich wyznaczeni byli specjalnie do tego celu służący zwani welariuszami (velarii) (W. Smith 1185). Ciekawą tego ilustracją jest wyobrażenie służącego odchylającego zasłonę zawieszoną w arkadzie, które widnieje na fragmencie datowanej na $V$ wiek tkaniny ściennej (w Museum of Fine Arts w Bostonie, il. 1) 2 $^{2}$.

Źródła ikonograficzne potwierdzają też umieszczanie zasłon w drzwiach kościoła. Szczególnie liczną grupę takich świadectw stanowią mozaiki topograficzne zachowane w kościołach Syrii i Palestyny (np. w kościele Świętych Męczenników w Tayyibat al-Imam w Syrii z 442 r., il. 5; w bazylice w Umm ar-Rasas w Jordanii z 586; w kościele św. Lota i Prokopiusza w Khirbat al-Mukhayyat w Jordanii z połowy VI wieku), jak również prze-

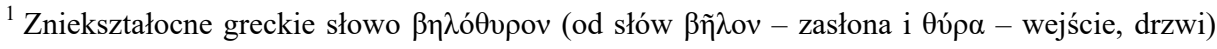
Zlatynizowana wersja tego określania - velothyra - pojawia się w późniejszych stuleciach w Liber Pontificalis.

${ }^{2} \mathrm{Nr}$ inw. 57.180, collections.mfa.org/objects/112017.
} 
chowywana obecnie w Luwrze mozaika ${ }^{3}$ ze wschodnich regionów śródziemnomorskich (il. 6). Zachowały się też świadectwa archeologiczne, które potwierdzają mocowanie zasłon nad drzwiami. Są to haki (przybierające czasami kształt ludzkiego palca) lub otwory po nich, które do dziś można zobaczyć w Santa Sabina w Rzymie (432 r.), w tzw. bazylice eufrazjańskiej w Poreč (ok. 553 r.), w Hagia Sophia w Konstanynopolu (537 r.) (i1.10).

Zasłony $\mathrm{w}$ drzwiach $\mathrm{z}$ jednej strony pełniły funkcje czysto praktyczne regulowały dopływ powietrza i światła oraz temperaturę, nie wpuszczały do środka owadów i ptaków. Z drugiej strony kotara umieszczona w progu budowli miała znaczenie symboliczne. Wyznaczała granicę - w domach między przestrzenią prywatną a publiczną, w kościołach zaś między przestrzenią sacrum a profanum. W wyobrażeniach budowli kościelnych, jakie widnieją na mozaikach (np. w tzw. bazylice eufrazjańskiej w Poreč - il. 4), zasłona w drzwiach zazwyczaj jest odchylona, a drzwi otwarte. Przyjęcie takiego rozwiązania w ikonografii wymownie podkreśla symboliczne znaczenie vela ad ostia. Odchylona zasłona przy otwartych drzwiach zdaje się nie tyle odgradzać, co wręcz zapraszać do wnętrza, jednocześnie jednak uświadamiając, że przekracza się granicę między dwoma różnymi światami.

Po wejściu do wnętrza trafiało się na kolejne symboliczne granice organizujące i hierarchizujące przestrzeń, a w ich wyznaczaniu dużą rolę odgrywały także tkaniny. Odgraniczano przede wszystkim prezbiterium i ołtarz. Już w czasach konstantyńskich jest poświadczone wydzielanie ołtarza za pomocą tzw. cancelli - niskich barierek z metalu, kamienia lub drewna.

Z czasem normą stało się wydzielanie w kościołach i sanktuariach chrześcijańskich nie tyle ołtarzy, co całych obszarów sprawowania liturgii, dostępnych już tylko dla kapłanów. Rezerwując dla nich miejsce w pobliżu ołtarza i oddzielając je od pozostałych uczestników mszy świętej, podkreślano hierarchiczność wspólnoty Kościoła oraz różnicę między klerem (ordo) a ludem (plebs). (IwaszkiewiczWronikowska, Cancelli 134-135)

Wiele wskazuje na to, że przestrzeń prezbiterium, jak i sam ołtarz, były wydzielane nie tylko za pomocą cancelli, ale również zasłon. Testamentum Domini, datowana na V wiek konstytucja kościelna, zawierająca opis liturgii eucharystycznej, stwierdza wyraźnie: „Velum (...) habeat altare (...) Locus presbiterorum sit intra velum prope locum commemorationis" (I, 19). Następnie wymienione są osoby uprawnione do przebywania w obrębie przestrzeni, której granicę wyznacza zasłona: „[episcopus] offerat intra velum

\footnotetext{
${ }^{3} \mathrm{Nr}$ inw. MA 3676.
} 
una cum presbyteris, diaconis, viduis canonicis, hypodiaconis, diaconissis, lectoribus (et) habentibus charismata" (I, 23). Zasłona wydzielała więc najświętsze miejsce w kościele i organizowała przestrzeń pod względem hierarchii we wspólnocie kościelnej. O zasłonach wydzielających ołtarz na znak szczególnej czci wspomina też Paulin z Noli w swoich „Pieśniach” (19, 662664): „velamine clausi / altaris faciem signo pietatis adornat”. Badacze zastanawiają się, czy chodzi tu o zasłony wiszące samodzielnie, czy o tkaniny zawieszone w cyborium, ponieważ w czasach Paulina (przełom IV/V wieku) stawianie tego rodzaju konstrukcji nad ołtarzem nie było jeszcze powszechną praktyką (Ebanista 217-219; Blaauw 985-986) ${ }^{4}$. Wcześniej natomiast niż ołtarze, bo już w IV wieku, zaczęto w ten sposób wyróżniać groby męczenników (Iwaszkiewicz-Wronikowska, Najstarsze miejsca 158-160; M.T. Smith 379-390). Takie cyboria - i zasłony między ich kolumnami - są przedstawione na datowanym na ok. 400 r. relikwiarzu z kości słoniowej z Samagher niedaleko Poli w Chorwacji (obecnie w Muzeum Archeologicznym w Wenecji).

W niektórych regionach chrześcijańskiego świata, na przykład w Syrii, część liturgii eucharystycznej dokonywała się prawdopodobnie za zasłoniętymi kotarami, oddzielającymi ołtarz bądź całe prezbiterium (Taft 42-43, 49; Mathews 165). Badacze przypuszczają, że odbywało się to w trakcie konsekracji chleba i wina, choć pozostaje niejasne, w których momentach zasuwano, a w których odsuwano zasłony (Taft 42-43; 49). Już Jan Chryzostom w homiliach wygłoszonych w 398 r. wspomina o odsuwaniu zasłon w trakcie Eucharystii (In 1 Cor hom. 36, 5; In Eph. hom. 3, 5), choć nie pisze o ich zasuwaniu. O zaciągniętych zasłonach mówi też Testamentum Domini, tekst powstały, zdaniem badaczy, najprawdopodobniej właśnie w Syrii: „Dum offert (episcopus) oblationem, velum portae (sanctuarii) sit expansum in signum aberrationis veteris populi, et offerat intra velum..." (I, 23 - red. Rahmani 35). Należy jednak zaznaczyć, że nie we wszystkich regionach da się znaleźć potwierdzenie podobnej praktyki (Taft 48-49).

Podstawową funkcją zasłon w cyborium zdaje się być nie tyle zasłanianie, co po prostu wydzielenie i dodatkowe podkreślenie świętości stojącego pod nim ołtarza. Cyborium i związana z nim symbolika wywodzi się głównie $\mathrm{z}$ ceremoniału dworskiego. Taką baldachimową strukturę stawiano przede wszystkim nad tronem cesarza, ewentualnie konsulów i urzędników repre-

\footnotetext{
${ }^{4}$ Stanie się nią natomiast od VI wieku (Blaauw 985-986).

${ }^{5}$ Thomas F. Mathews zdecydowanie odrzuca tę możliwość w przypadku wczesnobizantyjskich kościołów w Konstantynopolu (162-171)
} 
zentujących cesarską władzę (M.T. Smith 380-383; Bogdanović 14-15). Istnieje wiele wyobrażeń - już od IV wieku cesarzy i cesarzowych, a potem także Jezusa i Maryi - tronujących na tle aediculi lub baldachimu, których stałym elementem są rozsunięte na boki lub wiszące w tle zasłony. W takiej aranżacji ukazani są na przykład Konstancjusz II i Konstancjusz Gallus (il. 3) na miniaturach w Chronografie z 354 r. (cod. Barberini lat. 2154, Biblioteca Vaticana), cesarzowa Ariadna na plakietkach z kości słoniowej datowanych na 490-510 r. (w Kunsthistorisches Museum w Wiedniu) czy Chrystus i Maryja na dyptyku z 520-550 r. (w Bode Museum w Berlinie). Istnieją też wyobrażenia, na których pod baldachimem $\mathrm{z}$ odsuniętymi zasłonami ukazano krzyż (sarkofag z ok. 430 r. w Hagia Sophia; opus sectile na zachodniej ścianie nawy, nad głównymi drzwiami w Hagia Sophia; szklany kielich z VI-VII wieku w kolekcji Dumbarton Oaks).

Znaczenie uświetniające i wskazujące na wyjątkowy status określonej przestrzeni, osób w niej przebywających i czynności tam dokonywanych miały też zasłony oddzielające całe prezbiterium czy też wiszące $\mathrm{w}$ absydzie, gdzie zasiadał biskup ${ }^{6}$. Podobną funkcję pełniły kotary w prywatnych i publicznych bazylikach świeckich - w epoce późnego antyku cesarze i urzędnicy udzielali audiencji $\mathrm{w}$ pałacowych bazylikach, zasiadając na podwyższeniu $\mathrm{w}$ absydzie, u której wejścia wisiała zasłona, odsuwana $\mathrm{i}$ zasuwana w odpowiednich momentach (il. 2) (Stephenson 9-11)7. Wyraźnie oddają znaczenie zasłon w tym kontekście słowa św. Augustyna w pierwszym kazaniu na Ewangelię św. Mateusza (Sermo 51, 4.5.). Św. Augustyn zachęca do oddawania czci Chrystusowi tym bardziej, im bardziej nie rozumie się niektórych fragmentów Pisma Świętego, ponieważ te niezrozumiałe fragmenty są jak vela w domach czcigodnych ludzi. Im jest ich więcej, tym bardziej godna czci jest osoba, a przed tym, kto oddaje jej cześć, zasłona zostaje uniesiona:

Quanto enim quisque honoratior est, tanto plura vela pendent in domo eius. Vela faciunt honorem secreti: sed honorantibus levantur vela. Irridentes autem vela, et a velorum vicinitate pelluntur. Quia ergo transimus ad Christum, aufertur velamen.

Koryppus, VI-wieczny panegirysta, kilka razy wspomina o velach i velaminach mnożących się w pałacu cesarskim (In laudem lustini Augusti minoris I, 207; I, 255; III, 13; III, 67; III, 204; III, 255; III, 261; IV, 83-88; IV,

\footnotetext{
${ }^{6}$ Obok wzmianek w źródłach pisanych zwyczaj wieszania kotar w miejscu, w którym zasiadał biskup, jest opus sectile z wyobrażeniem wiszącej kotary za tronem biskupim w absydzie w Poreč.

${ }^{7}$ Zasłaniano i odsłaniano również posągi bogów w antycznych świątyniach, stwarzając $\mathrm{w}$ ten sposób wrażenie epifanii (W. Smith 1028; Williamson 323-324).
} 
208), podobnie jak św. Augustyn, widząc w zasłonach oznakę godności tego, co zasłaniają. Analogicznie w kościołach zwielokrotnienie zasłon przez umieszczenie ich w drzwiach wejściowych, na granicy prezbiterium, w cyborium ołtarzowym, w absydzie mogło potęgować emocje związane ze zbliżaniem się do sacrum.

Zasłony cyborium są określane w niektórych źródłach terminem kata-

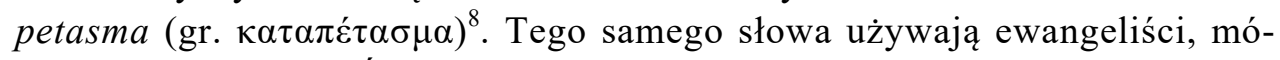
wiąc o zasłonie w Świątyni Jerozolimskiej, która rozdarła się na dwoje w chwili śmierci Jezusa (Mt 27,51; Mk 15,38; Łk 23,45). Już w listach apostolskich owa zasłona staje się metaforą ciała Jezusa. W Liście do Hebrajczyków czytamy: „On nam zapoczątkował drogę nową i żywą, przez

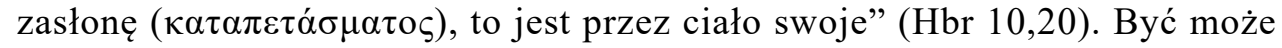
zasłona wydzielająca ołtarz w kościołach wczesnochrześcijańskich miała nawiązywać do tej ze Świątyni Jerozolimskiej, podkreślając sens sprawowanej na ołtarzu Eucharystii. Takie symboliczne znaczenie przypisywane zasłonom używanym do wydzielenia ołtarza jest dobrze udokumentowane dla późniejszych kościołów bizantyjskich (Lidov; Opstall 8), trudno natomiast znaleźć teksty potwierdzające to we wcześniejszym okresie.

Warto w tym miejscu wspomnieć, że do zasłony w Świątyni Jerozolimskiej nawiązywały zapewne tkaniny przedstawione na mozaikach w datowanych na V-VI wiek synagogach na terenie Izraela (np. w Hammath Tiberias, Beth Alpha, Beth Shean - il. 7-8) (Rosenthal-Heginbottom 155-160) ${ }^{9}$. Ukazują one zasłony w konstrukcjach interpretowanych zazwyczaj jako Aaron ha-kodesz. Ponieważ jednak archeologiczne świadectwa wieszania zasłon w niszach na Torę są nikłe (Rosenthal-Heginbottom 161), niektórzy badacze wyrażają wątpliwości, czy te przedstawienia odzwierciedlają autentyczną aranżację Aaron ha-kodesz, czy też są czysto symbolicznymi wyobrażeniami Świątyni, ,intended to convey a spiritual message related to the temple and it's cult" (Rosenthal-Heginbottom 169). Nawet jeśli to drugie przypuszczenie jest słuszne, to owe mozaiki i tak stanowią cenne świadectwo funkcjonowania motywu zasłony jako elementu wyróżniającego miejsca o szczególnym znaczeniu.

\footnotetext{
${ }^{8}$ Inne często spotykane określenie zasłon w cyboriach to tetravela (gr. $\tau \varepsilon \tau \rho \alpha ́ \beta \eta \lambda o v-$ dosłownie „cztery zasłony”), parapetesma (gr. $\pi \alpha \rho \alpha \pi \varepsilon ́ \tau \alpha \sigma \mu \alpha)$ (Bogdanović 35).

${ }^{9}$ Zdarzają się też przedstawienia zasłon u wejścia do budowli interpretowanej jako Świątynia (np. na mozaikach w samarytańskich synagogach w El-Khirbe i Khirbet Samara - il. 9) (RosenthalHeginbottom 162-164).
} 
Jeszcze jednym miejscem, gdzie wieszano zasłony w kościołach wczesnochrześcijańskich, są kolumnady oddzielające nawę główną od bocznych. Sugerują to otwory na drążki w trzonach kolumn, jakie sa poświadczone w wielu kościołach Grecji i Azji Mniejszej (np. w Pelli, na Kos, w Efezie, w Filippi, w Hieropolis i w Iasos (Peirano 164) ${ }^{10}$. Ilustracją zastosowania zasłon w interkolumniach może być słynna mozaika z kościoła Sant'Apollinare Nuovo w Rawennie, tradycyjnie interpretowana - zgodnie z napisem, którym jest opatrzona - jako „palatium” (il. 11). Niektórzy badacze uważają jednak, że w rzeczywistości przedstawia ona wnętrze bazyliki chrześcijańskiej (Ripoll 173). Nawet jeśli zechcemy trzymać się tradycyjnej interpretacji, to i tak owo przedstawienie daje wyobrażenie o tym, jak mogły wyglądać zasłony w kolumnadach naw kościołów. Na podstawie dostępnych źródeł trudno natomiast stwierdzić, czy zasłony w kolumnadach naw miały odseparowywać jakąś grupę wiernych (np. kobiety lub katechumenów), czy służyły innym, być może czysto dekoracyjnym celom (Doležalová 11-15). Niezależnie bowiem od wszystkich opisanych już funkcji wszelkiego rodzaju tkaniny stanowiły dekorację budowli i przyczyniały się do jej splendoru.

\section{SUROWCE, TECHNIKI I DEKORACJA ZASŁON}

W epoce późnego antyku najbardziej rozpowszechnionymi surowcami do wyrobu tkanin były ogólnie dostępne len i wełna, można więc spodziewać się, że większość zasłon była wykonana właśnie z nich. O lnianych zasłonach (vela linea) wspomina na przykład Charta Chornutiana (30-46, ed.

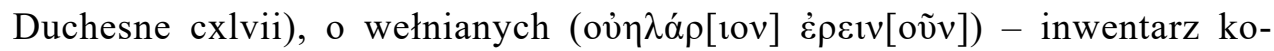
ścioła w Ibion (P. Grenf. II, 111). Najcenniejszym surowcem tkackim był natomiast jedwab. O jedwabnych zasłonach źródła mówią zazwyczaj w przypadku wielkich sanktuariów i wymieniają je wśród darów cesarskich. W IV wieku pątniczka Egeria (II, 25,8), opisując święto Epifanii w Bazylice Grobu Pańskiego, dodaje, że zarówno budowle wchodzące w skład tego zespołu (właściwa bazylika, rotunda Anastasis i sanktuarium Krzyża na Golgocie), jak i Bazylika Narodzenia w Betlejem są ozdobione jedwabnymi zasłonami

\footnotetext{
${ }^{10} \mathrm{Na}$ Zachodzie wskazać można tylko jeden taki przykład, a jest to Santa Sabina w Rzymie, aczkolwiek nie jest on jednoznaczny (Doležalová 13). Zasłony w interkolumniach naw staną się natomiast powszechne w Rzymie w późniejszym okresie, co potwierdzają wzmianki w Liber Pontificalis. Zasłony ,per diversos arcos” pojawiają się systematycznie od czasów pontyfikatu Hadriana I (772-775) - Liber Pontificalis, red. Duchesne 449 n.
} 
(vela oloserica). Nie były one jednak aż tak ekskluzywne, aby nie można ich było spotkać również w mniejszych kościołach. Charta Cornutiana (6-26) wymienia kilkanaście zasłon jedwabnych (vela olosirica) i półjedwabnych (tramosirica) ufundowanych przez niejakiego Flawiusza Valilę dla kościoła w Santa Maria in Cornuta niedaleko dzisiejszego Tivoli.

W niektórych źródłach (Testamentum Domini I, 19) jako surowiec,

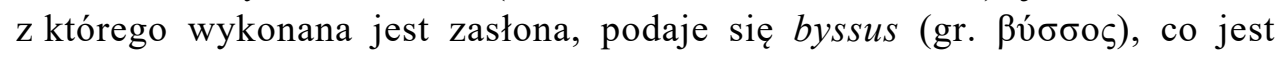
tłumaczone zazwyczaj jako „bisior” i utożsamiane z tzw. morskim jedwabiem. Tymczasem - jak dowodzą najnowsze badania - niezależnie od tego, że jedwab morski rzeczywiście istniał w starożytności, w większości przypadków, gdy w starożytnych źródłach używa się słowa byssus, chodzi po prostu o delikatne i białe tkaniny o splocie płóciennym, najczęściej zapewne lniane (Meader). W starożytności istniało wiele gatunków lnianych tkanin o splocie płóciennym - mogły być grube i szorstkie, ale też cienkie i niemal przezroczyste jak te, które nazywamy dziś batystem. Badacze przypuszczają, że słowo byssus odnosiło się zazwyczaj właśnie do jakości tkaniny, a nie do użytej przędzy, i proponują używać go w oryginalnym brzmieniu, nie tłumacząc (Maeder 504). Byssus był ceniony również ze względu na lśniącą biel, która była symbolem czystości i niewinności (Maeder 501, przyp. 5). Expressis verbis znaczenie białego byssus wykłada Testamentum Domini (I, 19), mówiąc o zasłonach ołtarza: „Velum ex bysso pura confectum habeat altare, quoniam est immaculatum". Być może z byssusu były także zasłony, o których wspomina Paulin z Noli w Pieśni 14, 98-99, zaczynając od wzmianki o nich opis wspaniałości odnowionej przez siebie świątyni: „Aurea nunc niveis ornantur limina velis”.

Najcenniejsze zasłony były farbowane purpurą ${ }^{11}$ i zdobione złotem. O purpurowych i obramowanych złotymi pasami zasłonach (vela blattea auroclaa paragaudata) mowa jest na przykład w Charta Cornutiana $(15)^{12}$. O złotych (aurotexta) lub dekorowanych złotymi pasami (auroclava) zasłonach wspominają też cytowany już wyżej Chronicon Paschale i Egeria (II 25, 8: ,uela

\footnotetext{
${ }^{11}$ Purpurę uzyskiwano z niektórych gatunków ślimaków morskich należących do rodziny rozkolcowatych (Muricidae) - Murex trunculus i Murex brandaris (Bogensperger). Tkaniny barwione purpurą przybierały różne odcienie - od brunatno-czerwonego po fioletowo-niebieski czy prawie czarny. Pozyskanie prawdziwej purpury było trudne i czasochłonne, co przekładało się na niezwykle wysokie koszty tego barwnika i sprawiało, że tkaniny purpurowe były wyznacznikiem iście cesarskiego splendoru. Ci, którzy nie mogli sobie pozwolić na prawdziwą purpurę, używali tkanin w zbliżonym kolorze uzyskanym z połączenia czerwonych i niebieskich barwników, np. z marzanny farbiarskiej i indygowca (Reinhold).

${ }^{12} \mathrm{Na}$ temat tego i innych terminów używanych na oznaczenie purpury zob. Bogensperger.
} 
uides, auroclaua oleserica sunt, si cortinas uides, similiter auroclaue oleserica sunt"). Choć nie wiemy nic na temat zasłon w kościołach z IV i V wieku w Rzymie, to można się spodziewać, że również były wykonane $\mathrm{z}$ najdroższych materiałów ${ }^{13}$.

W mniejszych i uboższych kościołach dominowały zapewne zasłony lniane i wełniane, które jednak również były wysoko cenione. O takich zasłonach wspomina na przykład Paulin z Noli, który bardzo dbał o splendor odnowionego przez siebie kościoła (Brown). W Pieśni 18,29-31 mówi o ufundowanych przez hojnych darczyńców, przeznaczonych do umieszczenia w drzwiach (foribus), pięknych zasłonach (pulcra vela) wykonanych z czystego, lśniącego lnu (puro splendida lino) lub też z tkanin pokrytych kolorowymi kształtami (coloratis textum fucata figuris) - zapewne w technice tapiserii.

Jak wyglądała taka dekoracja, można sobie wyobrazić na podstawie zachowanych do dziś zasłon pochodzących z domów prywatnych. Oczywiście żadna zasłona nie miała szans przetrwać do naszych czasów w pierwotnym kontekście architektonicznym, natomiast sporo zasłon pochodzących z domów prywatnych i użytych wtórnie jako całuny zachowało się w późnoantycznych grobach w Egipcie. Było to możliwe dzięki zmianom w zwyczajach pogrzebowych i konserwującym właściwościom gorących i suchych pustynnych piasków. W epoce późnego antyku zmarłych już nie mumifikowano, lecz składano do grobów (zazwyczaj prostych grobów jamowych) w ubraniu i owijano ich dodatkowo wieloma warstwami różnego rodzaju tkanin domowego użytku - np. koców, narzut, tkanin ściennych, podłogowych, zasłon (Dunand i Lichtenberg 123-130; Dunand 169-179). Wszystkie te tkaniny mają wiele cech wspólnych i czasami trudno stwierdzić z całkowitą pew-

\footnotetext{
${ }^{13}$ Co zastanawiające, najważniejsze źródło do poznania wyposażenia rzymskich kościołów, jakim jest Liber Pontificalis (księga zawierająca biogramy papieży, a przy okazji listy darów ofiarowywanych przez nich i przez cesarzy do kościołów w Rzymie), w ogóle nie wspomina o zasłonach (ani innych tkaninach) w okresie IV-V wieku. Pierwsza wzmianka o zasłonach pochodzi dopiero z czasów papieża Hormisdasa (514-523), gdzie jest mowa o vela holoserica duo ofiarowanych przez biskupa Konstantynopola, Epifaniusza, dla kościoła Świętych Apostołów w Rzymie. W ciągu VI wieku pojawia się jeszcze zaledwie kilka wzmianek o tkaninach, przy czym oprócz wspomnianych wyżej vela mowa jest za każdym razem o pallea / pallia (ed. Duchesne 276, $285,303)$. Ten termin jest interpretowany przez niektórych badaczy jako zasłony między kolumnami naw lub w cyboriach (Martiniani-Reber 291), ale wydaje się to kontrowersyjne, ponieważ etymologia tego słowa wskazywałaby raczej na jakiegoś rodzaju okrycia. Ilość zasłon (vela, velothyra, tetravela) wymienianych w Liber Pontificalis wzrasta znacząco w VII, a zwłaszcza VIII wieku (ed. Duchesne 343, 363, 374, 383, 401, 418, 432, 464, 499 n.; Petriaggi 38-39), jest to jednak okres, który wykracza poza ramy przyjęte w niniejszym artykule.
} 
nością, czy mamy do czynienia z zasłoną. Choć istnieją surowce, techniki i sposoby dekoracji, które ze względów praktycznych są odpowiedniejsze dla konkretnych celów (np. dla zasłon tkaniny dwustronne), to większość z nich stosowano niezależnie od konkretnej funkcji tekstyliów. W niektórych przypadkach zachowały się jednak elementy, które pozwalają z całkowitą pewnością stwierdzić, że pierwotnie dana tkanina była używana jako zasłona. Są to sznurki lub pętelki do zamocowania jej na hakach lub drążkach, jak również wzmocniona górna krawędź (Colburn, „Loops”), a czasami regularne dziurki wzdłuż brzegu, pozostałe po jakimś systemie mocowania (Evans i Ratliff 80 , nr kat. 50 - w takich przypadkach można też zastanawiać się, czy nie mamy do czynienia z tkaniną ścienną).

Ponieważ len trudno przyjmuje barwniki, lniane tkaniny pozostawione w naturalnym kolorze (lub wybielone) dekorowano barwnymi wełnianymi wstawkami lub jedwabnymi aplikacjami o różnych kształtach, zawierających rozmaite motywy geometryczne, roślinne, zwierzęce czy też przedstawienia postaci ludzkich. Najczęściej spotykanymi typami takich wstawek były biegnące wzdłuż krawędzi taniny lub w jej centralnych partiach pasy (clavi), umieszczane $\mathrm{w}$ narożach motywy przypominające grecką literę gamma $\left(\Gamma\right.$, tzw. gammadia $\left.{ }^{14}\right)$, okrągłe orbiculi i kwadratowe segmenta, jak również wstawki w kształcie gwiazdy. Dekorację w postaci gammadiów i segmentów widzimy na przykład na przedstawieniu tkaniny w wejściowej arkadzie „Palatium" na mozaice w San Apollinare Nuovo w Rawennie (il. 11), w wyobrażeniach arkad ze stojącymi w nich biskupami na mozaikach w San Apollinare in Classe (il. 12).

Wiele motywów stosowano zarówno na tkaninach przeznaczonych do użytku w kościołach, jak i w budowlach świeckich. Sądząc po źródłach ikonograficznych oraz zachowanych przykładach tkanin użytkowych, jednym z najczęściej spotykanych wzorów był tzw. rzucik (ang. scattered pattern, niem. Streumuster), składający się z rozmieszczonych pojedynczo w regularnych odstępach drobnych motywów kwiatowych, a czasami również zwierzęcych (zwłaszcza ptaków). Czasami motywy te były wpisywane w romboidalną siatkę. Pod względem częstotliwości występowania pierwsze miejsce wśród motywów typowych dla rzuciku zajmuje niewątpliwie tzw. rozeta krzyżowa

\footnotetext{
${ }^{14}$ Ta nazwa pojawia się po raz pierwszy w Liber Pontificalis dopiero od końca VIII wieku i wiążę się z nią wiele kontrowersji oraz nieścisłości w definiowaniu, wynikających z późniejszych interpretacji (Szymaszek), lecz w literaturze dotyczącej starożytnych tekstyliów przyjęło się określać tym terminem wyłącznie wstawki w kształcie dwóch stykających się pod kątem prostym pasów i stosuje się go również w odniesieniu do tkanin wcześniejszych niż pierwsze użycie tego słowa w Liber Pontificalis.
} 
(ang. cross-rosette, niem Kreuzrosette) ${ }^{15}$. Jest to widziany $\mathrm{z}$ góry kwiat róży ${ }^{16}$ złożony $\mathrm{z}$ czterech sercowatych płatków w różnych odcieniach różów i czerwieni, zazwyczaj poprzedzielanych zielonymi łodyżkami, które tworzą wyraźny zarys krzyża; bardzo często występuje też kwiat róży ukazany z profilu (il. 13). Najprawdopodobniej to właśnie o takiej dekoracji mówi Charta Cornutiana (27 i 46), wymieniając „vela rosulata”. Zachowało się wiele dekorowanych $\mathrm{w}$ ten sposób tkanin pochodzących $\mathrm{z}$ kontekstu świeckiego ${ }^{17}$, jak również ich przedstawień („Palatium”, il. 11). Prawdopodobnie to właśnie taką dekorację przedstawiono w schematyczny sposób na zasłonie wiszącej w drzwiach kościoła na mozaice w Poreč (il. 4). O uniwersalności tego wzoru świadczą też przedstawienia w późnoantycznych synagogach (np. w Beth Shean, Beth Alpha - il. 7-8, w El-Khirbe - il. 9).

Do często stosowanych motywów - zarówno w dekoracji tkanin używanych w domach, jak i w kościołach - należał z pewnością krzyż. W Egipcie zachowało się wiele tkanin użytkowych zdobionych krzyżami i monogramami Chrystusa, na przykład datowana na V-VI wiek zasłona w Minneapolis Institute of Arts z umieszczonym na tle rzuciku kwiatowego wielkim crux gemmata ze skrzyżowaniem ramion ujętym $\mathrm{w}$ wieniec (il. 14) ${ }^{18}$ i zasłona w British Museum z wiktoriami trzymającymi równoramienny krzyż w wieńcu, również z rzucikiem w tle ${ }^{19}$. Łatwo wyobrazić sobie tego rodzaju zasłony wiszące w budowlach kościelnych.

Zasłony miewały też dekorację figuralną, która mogła być tkana lub malowana. Ze źródeł pisanych i archeologicznych wynika, że przynajmniej od IV wieku często umieszczano na różnego rodzaju tkaninach wizerunki Jezusa, Maryi, świętych oraz całe sceny biblijne ${ }^{20}$. Ów zwyczaj budził gwałtowny sprzeciw niektórych duchownych. Wart przytoczenia w całości jest fragment listu żyjącego w IV wieku (zm. 403) biskupa Salaminy, Epifaniusza, do Jana, biskupa Jerozolimy (Epistula ad Joannem Hierosolimi-

\footnotetext{
${ }^{15}$ Nota bene rzucik z wykorzystaniem motywu rozety krzyżowej czy kwiatu w profilu był również bardzo popularny na mozaikach późnoantycznych (Maguire, Firm flowers).

${ }^{16}$ Niektórzy badacze są zdania, że ów kwiat to malwa i może mieć symboliczne znaczenie związane z przypisywanymi malwie właściwościami (Matveyeva), ta interpretacja nie wydaje się jednak przekonująca.

${ }^{17} \mathrm{Na}$ przykład w Metropolitan Museum of Art, nr inw. 12.182.45 - zob. www.metmuseum. org/art/collection/search/446223.

${ }^{18} \mathrm{Nr}$ inw. 83.126 - zob. collections.artsmia.org/art/3149/curtain-coptic.

${ }^{19} \mathrm{Nr}$ inw. EA29771 - zob. www.britishmuseum.org/ collection/ object/Y_EA29771.

${ }^{20}$ Przedstawieniami Jezusa, Maryi, świętych, etc. dekorowano nie tylko zasłony i inne tkaniny użytkowe, ale też ubrania, co bulwersowało np. Asteriusza, biskupa Amazji (Homilia o bogaczu i Łazarzu, thum. Strzelecka 216-217).
} 
tanum, tłum. Czuj 328). Nie tylko dostarcza on cennych informacji na temat zasłon w kościołach, ale również wspomina o zwyczaju chowania zmarłych we wtórnie użytych tkaninach użytkowych:

Przybyłem do wsi zwanej Anablata, gdzie przechodząc ujrzałem płonącą lampkę i zapytałem, co by to było za miejsce, a gdym dowiedział się, że kościół, wstąpiłem, by się pomodlić. Otóż zauważyłem tam zasłonę wiszącą we drzwiach, farbowaną i malowaną, noszącą obraz jakoby Chrystusa lub jakiegoś świętego, nie pamiętam dobrze, czyj to był obraz. Gdy więc widziałem, że w kościele Chrystusowym wbrew powadze Pisma św. wisi obraz człowieka, zerwałem go i poradziłem stróżom tego miejsca, by raczej owinęli w tę materię ubogiego nieboszczyka i wynieśli. Oni, szemrząc przeciw temu, mówili: «Jeśli chciał zrywać, sprawiedliwie było, by dał inną zasłonę zamiast tej». Gdym to usłyszał, przyobiecałem, że dam i że zaraz zostanie przysłana. Tymczasem powstała pewna zwłoka, gdyż szukałem, by jak najlepszą posłać za tamtą zasłonę; mniemałem bowiem, że przyjdzie mi posłać z Cypru. Teraz zaś posłałem, co mogłem znaleźć, i proszę, byś kazał kapłanowi tego miejsca przyjąć przez lektora zasłonę posłaną przeze mnie, a na przyszłość zakaż w kościele Chrystusowym wieszać tego rodzaju zasłony, kłócące się z naszą religią.

Epifaniusz protestował też przeciwko wizerunkom - m.in. na zasłonach w liście skierowanym do cesarza Teodozjusza (Epistula ad Theodosium imperatorem - thum. Dylewska 565):

Tak więc zasłony pokryte przewrotnie malowidłami apostołów, proroków, a nawet samego Pana naszego Chrystusa, należy wszystkie zebrać i usunąć z kościołów, baptysteriów, domów i martyriów oraz przeznaczyć na pochówek dla biednych...

W tym czasie tylko nieliczni podzielali pogląd Epfianiusza, toteż zachowało się stosunkowo wiele tkanin z potępianymi przez niego przedstawieniami figuralnymi. Przykładem takiej malowanej zasłony jest datowana na 2. Połowę IV wieku, a więc na czasy Epifaniusza, tkanina w Abbeg Stiftung w Riggisbergu (il. 15) ${ }^{21}$, gdzie na zabarwionym na ciemnoniebieski kolor lnianym płótnie ukazano $\mathrm{w}$ trzech rejestrach sceny starotestamentowe, zaczynając od Adama i Ewy, a kończąc na przejściu Izraelitów przez Morze czerwone (Kötzsche, Der bemalt Behang).

„Obrazy” na tkaninach można było też uzyskać za pomocą czysto tkackiej techniki tapiserii. Najbardziej znanym przykładem takiej tkaniny jest datowana na VI wiek tzw. ikona z Cleveland, tapiseria przedstawiająca tronującą

\footnotetext{
${ }^{21} \mathrm{Nr}$ inw. inv. no. 4185 .Wymiary: wys. $146 \mathrm{~cm}$, szer.. $436 \mathrm{~cm}$.
} 
Maryję flankowaną przez archaniołów, Pantokratora i Apostołów ${ }^{22}$. Stanowiła ona raczej tkaninę ścienną niż zasłonę, ale tego rodzaju tapiserie mogły też wisieć w przegrodach chórowych (Stephenson 14-15). Tkaniny ścienne w architekturze starożytnej i późnoantycznej to temat na osobne opracowanie, warto jednak przynajmniej zasygnalizować tę kwestię jako istotną dla wyobrażenia sobie całej pierwotnej dekoracji wczesnochrześcijańskich kościołów.

\section{PODSUMOWANIE}

Zasłony we wszelkiego rodzaju budowlach starożytnych, również w kościołach, pełniły ważne funkcje praktyczne (zwłaszcza kotary wiszące w drzwiach wejściowych, które regulowały temperaturę, a także izolowały od niepożądanych gości, takich jak owady czy ptaki). Jednocześnie miały znaczenie symboliczne, wyznaczając granice świętości miejsc i podkreślając godność znajdujących się w ich obrębie osób (lub relikwii). W kościołach na tę wywodzącą się w dużej mierze ze świeckiego kontekstu symbolikę być może nakładały się dodatkowo skojarzenia z zasłoną w Świątyni Jerozolimskiej.

Oprócz funkcji praktycznych i symbolicznych zasłony odgrywały niebagatelną rolę $\mathrm{w}$ percepcji budowli i właśnie ją chciałabym na koniec podkreślić. Wczesnochrześcijańskie kościoły były miejscami bogato dekorowanymi na niemal wszystkie możliwe sposoby: marmurowymi okładzinami, lśniącymi mozaikami, barwnymi freskami, reliefami na kapitelach i innych elementach architektonicznych, kolorowym szkłem, złotymi i srebrnymi lampami, krzyżami wysadzanymi drogocennymi kamieniami, tkaninami o różnych strukturach i wzorach. Rozmaite materiały, techniki, kolory i motywy dawały lubiany w starożytności efekt poikilia (Grand-Clément). Jak ujęła to jedna $\mathrm{z}$ badaczek, również $\mathrm{w}$ kościołach wczesnochrześcijańskich obecna jest ,this passion for colour, complex variation, effects of light, contrast, and the interaction of media as essential elements in the formation of beauty" (Bolman 123). Wszystko to ucieleśniają tkaniny - śnieżnobiałe, purpurowo-złote lub „inkrustowane” kolorowymi wstawkami, o różnych strukturach osiąganych rozmaitymi technikami tkackimi, matowe lub połyskujące, a w dodatku tworzące silne, ,interakcje mediów” przez kontrast z marmurami, mozaikami, etc. Sądząc po opisach, takich jak relacja Egerii czy wiersze Paulina z Noli, zasłony oszałamiały wspaniałością i przyczyniały się do podniesienia splendoru miejsc świętych. Warto o tym pamiętać, próbując

\footnotetext{
${ }^{22}$ Cleveland Museum of Art, nr inw. 1967.144 - zob. www.clevelandart.org/art/ 1967.144.
} 
wyobrazić sobie oryginalny wygląd wczesnochrześcijańskich kościołów, których dekoracja zachowała się dziś zaledwie szczątkowo, a zupełnie nieobecne są w nich (i w większości ich opracowań) tak nieodłączne pierwotnie tkaniny.

\section{BIBLIOGRAFIA}

\section{ŹRÓDŁA}

Acta Synodalia ab anno 553 ad annum 600, red. Henryk Pietras, Synody i kolekcje praw, t. XII, Wydawnictwo WAM 2020, ss. 208-212 = Concilia Hispaniae, red. Juan Vives, Instituto Enrique Flórez, 1963, ss. 146-150.

Asteriusz z Amazji, Homiliae I, PG 40, 163-226. Tłum. Anna Strzelecka: Święty Asteriusz z Amazji, „Homilie”, Teologia Patrystyczna, nr 5, 2008, ss. 215-249.

Augustyn, Sermones in Matthaeum. 1 id est Sermones LI-LXX [51-70] secundum ordinem vulgatum, insertis etiam novem sermonibus post Maurinos repertis, CCSL 41Aa, red. Pierre-Patrick Verbraken i François Dolbeau, Brepols 2008.

„Charta Cornutiana”. Regesto della Chiesa di Tivoli, red. Luigi Bruzza, Tipografia della Pace 1880 (repr. w Liber Pontificalis, red. Louis Duchesne, E. Thorin, 1886, ss. cxlvi-cxlvii).

Chronicon Paschale, wyd. Ludwig August Dindorf, E.Weber, 1832.

Egeria. Itinerarium seu Peregrinatio ad loca Sancta, red. P. Maraval, SCh 296, Paris, 1982. Thum. Piotr Iwaszkiewicz: Egeria, „Pielgrzymka do miejsc świętych”. Do Ziemi Świętej. Najstarsze opisy pielgrzymek do Ziemi Świętej (IV-VIII w.), red. Piotr Iwaszkiewcz, Ojcowie żywi XIII, Wydawnictwo WAM, 1996, ss. 125-229.

Epifaniusz z Salaminy. „Epistula ad Theodosium imperatorem”. Thum. Magdalena Maria Dylewska: Epifaniusz z Salaminy, „Mowy przeciwko obrazom”. Vox Patrum, nr 22, 2002, ss. 562-564.

Epifaniusz z Salaminy. Epistula ad Joannem Hierosolimitanum 9, PG 43, 390BC.

Hieronim, Epistula 51,9, PL 22,526-527 = CSEL 54, 411. Tłum. J. Czuj: Św. Hieronim, Listy, I, Instytut Wydawniczy Pax, 1952.

Koryppus. In laudem Iustini Augusti minoris, red. Averil Cameron, Bloomsbury Publishing 2000. Tłum. Bartosz Jan Kołoczek: Flawiusz Kreskoniusz Koryppus. Joannida. Pochwała Justyna. Historia Iagellonica, 2016.

Le Liber Pontificalis, vol. I, red. Louis Duchesne, E. Thorin, 1886. Tłum. Przemysław Szewczyk (1-90), Małgorzata Jesiotr (91-96): „Liber pontificalis I-XCVI (usque ad annum 772). Księga pontyfików 1-96 (do roku 772)". Wydawnictwo WAM, 2014-2015.

Paulin z Noli, „Pieśni”. S. Pontii Meropii Paulini Nolani Opera pars II. Carmina, Indices et Addenda, red. Guilelmus de Hartel, Verlag der Österreichischen Akademie der Wissenschaften, 1999 (Corpus Scriptorum Ecclesiasticorum Latinorum XXX).

P. Grenf. II, 111, wyd. Bernard P. Grenfell i Arthur S. Hunt, New classical fragments and other Greek and Latin papyri, Cisalpino-Goliardica, 1972 (wyd. 2.) = Select Papyri. Private Affairs. Accounts and Lists. LCL 266, 432-435. 
Testamentum Domini Nostri Jesu Christi, red. Ignatius Ephraem II Rahmani, Sumptibus F. Kirchheim, 1899.

\section{OPRACOWANIA}

Ball, Jennifer L., „Textiles. The emergence of a Christian identity in cloth”. The Routlege Handbook of Early Christian Art, red. Robin M. Jensen, Mark D. Ellison, Routledge, 2018, ss. 221-239.

Ball, Jennifer L. „Rich Interiors: The Remnant of a Hanging from Late Antique Egypt in the Collection of Dumbarton Oaks". Catalogue of the Textiles in the Dumbarton Oaks Byzantine Collection, red. Gudrun Bühl and Elizabeth Dospěl Williams, Washington, DC, 2019, www.doaks.org/resources/textiles/essays/ball. Dostęp 23.03.2021.

Bogdanović, Jelena. The Framing of Sacred Space: The Canopy and the Byzantine Church. Oxford University Press, 2017.

Bogensperger, Ines. „Purple and its Various Kinds in Documentary Papyri”. Textile Terminologies from the Orient to the Mediterranean and Europe, 1000 BC to 1000 AD, red. Salvatore Gaspa, Cécile Michel, Marie Louise Bech Nosch, Zea Books, 2017, ss. 235-249.

Bolman, Elizabeth S. „Veiling Sanctity in Christian Egypt: Visual and Spatial Solutions”. Thresholds of the sacred. Architectural, art historical, liturgical, and theological perspectives on religious screens, East and West, red. Sharon E. J. Gerstel, Cambridge, 2006, ss. 72-104.

Bolman, Elizabeth S., „Painted Skins: The Illusions and Realities of Architectural Polychromy, Sinai and Egypt". Approaching the Holy Mountain. Art and Liturgy at St Catherine's Monastery in the Sinai, red. Sharon E. J. Gerstel, Turnhout, 2010, ss. 119-142.

Brown, Peter. „Commercium Spirituale: 'A Spiritual Exchange,' Paulinus of Nola and the Poetry of Wealth”. Essays in Honor of Jeremy du Quesnay Adams, red. Stephanie Hayes-Healy, Palgrave Macmillan 2005, ss. 79-98.

Caseau, Béatrice. „Objects in Churches. The Testimony of Inventories”. Objects in Context, Objects in Use, red. Luke Lavan, Ellen Swift, Toon Putzeys, Brill, 2008, ss. 551-579.

Caseau, Béatrice. „Experiencing the Sacred”. Experiencing Byzantium, red. Claire Nesbitt i Mark Jackson, Ashgate Publishing, 2013, ss. 59-77.

Ćirić, Jasmina S. „'For the Entrance to the Tent Make a Curtain': Ornaments, Curtains and Passages in Early Byzantine Sacred Context". Niš and Byzantium XVI. International symposium (Niš, 3-5 june 2017), red. Miša Rakocija, Niš, 2018, ss. 221-232.

Clarysse, Willy, i Karolien Geens. „Textiles and Architecture in the Graeco-Roman and Byzantine Egypt". Clothing the house. Furnishing textiles of the 1st millennium AD from Egypt and neighbouring countries, red. Antoine de Moor i Cäcilia Fluck, Lannoo, 2009, ss. 38-47.

Colburn, Kathrin. „Loops, Tabs, and Reinforced Edges: Evidence for Textiles as Architectural Elements". Catalogue of the Textiles in the Dumbarton Oaks Byzantine Collection, red. Gudrun Bühl and Elizabeth Dospěl Williams, Washington, DC, 2019, www.doaks.org/ resources/textiles/essays/colburn. Dostęp 23.03.2021.

Colburn, Kathrin. „Materials and Techniques of Late Antique and Early Islamic Textiles Found in Egypt". Byzantium and Islam: Age of Transition, red. Helen C. Evans i Brandie Ratliff, The Metropolitan Museum of Art, 2012, ss. 161-163

Dauterman Maguire, Eunice. „Curtains at the Threshold: How They Hung and How They Performed". Catalogue of the Textiles in the Dumbarton Oaks Byzantine Collection, red. Gudrun Bühl i Elizabeth Dospěl Williams, Washington, DC, 2019, www.doaks.org/ resources/ textiles/essays/maguire. Dostęp 23.03.2021. 
Dauterman Maguire, Eunice. „Firm flowers in the artifice of transience”. The Eloquence of Art: Essays in Honour of Henry Maguire, red. Andrea Olsen Lam i Rossitza Schroeder, Taylor and Francis, 2020, ss. 162-187.

Doležalová, Klara. „Lateral Naves in the Mediterranean Space and Their Functions in Late Antiquity", Uniwersytet Masaryka w Brnie, 2019, is.muni.cz/th/mp6h2/ Dolezalova_ Lateral_Naves.pdf. Dostęp 23.03.2021.

Dunand, Françoise, i Roger Lichtenberg. Mummies and Death in Egypt. Cornell University Press, 2006.

Dunand, Françoise. Between Tradition and Innovation: Egyptian Funerary Practices in Late Antiquity, Egypt in the Byzantine World, 300-700, red. Roger S. Bagnall, Cambridge University Press, 2007, ss. 163-184.

Ebanista, Carlo. „Spatiosa altaria: le installazioni liturgiche paleocristiane e medievali del santuario di Cimitile". Ingenita curiositas. Studi sull'Italia medievale per Giovanni Vitolo, red. Bruno Figliuolo, Rosalba di Meglio i Antonella Ambrosio, I, Laveglia \& Carlone, 2018, ss. 213-258.

Grand-Clément, Adeline. „Poikilia”. A Companion to Ancient Aesthetics, red. Pierre Destrée i Penelope Murray, Wiley-Blackwell, 2015, ss. 406-421.

Fluck, Cäcilia. „The Use of Textiles in Early Christian Churches - Evidence from Egypt (Fourth to Seventh Centuries)". Church Building in Cyprus (Fourth to Seventh Centuries): A Mirror of Intellectual Contacts in the Eastern Mediterranean, red. Marletta Horster, Doria Nicolaou i Sabinne Rogge, Waxmann, 2018, ss. 247-266.

Fluck, Cäcilia i Helmecke, Gisela. „Egypt's Post-Pharaonic Textiles”. Coptic Civilization: Two Thousand Years of Christianity in Egypt, red. Gawdat Gabra, The American University in Cairo Press, 2014, ss. 237-260.

Iwaszkiewicz-Wronikowska, Bożena. „Cancelli, czyli najstarsze przykłady wyznaczania granic świętości w chrześcijańskich miejscach kultu”. Sympozja kazimierskie poświęcone kulturze świata późnego antyku $i$ wczesnego chrześcijaństwa, t. VIII: Granice świętości w świecie późnego antyku, red. Bożena Iwaszkiewicz-Wronikowska i Anna Głowa, Towarzystwo Naukowe KUL, 2013, ss. 123-147.

Iwaszkiewicz-Wronikowska, Bożena. „Najstarsze swiadectwa kultu meczennikóvvw Rzymie”. Sympozja kazimierskie poświęcone kulturze świata późnego antyku i wczesnego chrześcijaństwa, t. IV: Męczennicy w świecie późnego antyku, red. Bożena Iwaszkiewicz-Wronikowska, Towarzystwo Naukowe KUL, 2004, ss. 149-174.

Kötzsche, Lieselotte. Der bemalte Behang in der Abegg-Stiftung in Riggisberg. Eine alttestamentliche Bildfolge des 4. Jahrhunderts (Riggisberger Berichte). Abegg Stiftung, 2004.

Maeder, Felicitas. „Irritating Byssus - Etymological Problems, Material facts, and the Impact of Mass Media". Textile Terminologies from the Orient to the Mediterranean and Europe, 1000 BC to 1000 AD, red. Salvatore Gaspa, Cécile Michel i Marie Louise Bech Nosch, Zea Books, 2017, ss. 500-519.

Martiniani-Reber, Marielle. „Tentures et textiles des églises romaines au haut Moyen Âge d'après le Liber Pontificalis". Mélanges de l'école française de Rome, nr 111, 1999, ss. 289-305.

Matveyeva, Julia. Crossed Flowers and Circles: An Evolution of Eucharistic Symbols, Ayxiaitepa, 2016.

McLaughlin, Raoul. The Roman Empire and the Silk Routes: The Ancient World Economy and the Empires of Parthia, Central Asia and Han China, Pen \& Sword History, 2016. 
Mundell Mango, Marlia. „The Monetary Value of Silver Revetments and Objects Belonging to Churches". Ecclesiastical Silver Plate in Sixth-Century Byzantium: papers of the symposium held May 16 - 18, 1986 at the Walters Art Gallery, Baltimore and Dumbarton Oaks, Washington, D.C., red. Marlia Mundell Mango i Susan Boyd, Dumbarton Oaks Research Library and Collection, 1992, ss. 123-136.

Osborne, John. „Textiles and Their Painted Imitations in Early Medieval Rome”. Papers of the British School at Rome, $\mathrm{nr}$ 60, 1992, ss. 309-351.

Peirano, Diego. „Internal Arrangements in Some Early Christian Basilicas of the Eastern Mediterranean". Hortus Artium Medievalium, nr 24, 2018, ss. 162-170.

Peschlow, Urs. „Dividing Interior Space in Early Byzantine Churches: The Barriers Between the Nave and Aisles". Thresholds of the Sacred: Architectural, Art Historical, Liturgical, and Theological Perspectives on Religious Screens, East and West, red. Sharon E.J. Gerstel., Cambridge, Dumbarton Oaks Research Library and Collection, ss. 2006, ss. 52-71.

Petriaggi, Roberto, „Utilizzazione, decorazione e diffusione dei tessuti nei corredi delle basiliche cristiane secondo il Liber Pontificalis (514-795)". Prospettiva, nr 39, 1984, ss. 37-46.

Reinhold, Meyer. History of Purple as A Status Symbol in Antiquity. Collection Latomus, 1970.

Ripoll, Gisela. „Los tejidos en la arquitectura de la Antigüedad tardía. Una primera aproximación a su uso y función". Antiquité Tardive, nr 12, 2004, ss. 169-182.

Rosenthal-Heginbottom, Renate. „The curtain (parochet) in Jewish and Samaritan synagogues Curtains are depicted on the mosaic floors of a few Late Antique synagogues". Clothing the house. Furnishing textiles of the 1st millennium AD from Egypt and neighbouring countries, red. Antoine de Moor, Cäcilia Fluck, Lannoo, 2009, ss. 155-169.

Schrenk, Sabine. „(Wall-)Hangings Depicted in Late Antique Works of Art? The Question of Function". Clothing the House: Furnishing Textiles of the 1st Millennium AD from Egypt and Neighbouring Countries, red. Antoine De Moor and Cäcilia Fluck, Lannoo, 2009, ss. 147-154.

Smith, Molly Teasdale. „The Development of the Altar Canopy in Rome”. Rivista di archeologia cristiana, nr 50, 1974, ss. 379-414.

Smith, William. Dictionary of Greek and Roman Antiquities, J. Murray, 1890.

Stauffer, Annemarie. „Imports and Exports of Textiles in Roman Syria”. Topoi. Orient-Occident, Suppl. 8, 2007, ss. 357-373.

Stephenson John W. „Veiling the Late Roman House”. Textile History, nr 45, 2014, ss. 3-31.

Szymaszek, Maciej. „The Textile Term gammadia”. Textile Terminologies from the Orient to the Mediterranean and Europe, 1000 BC to 1000 AD, red. Salvatore Gaspa, Cécile Michel, Marie Louise Bech Nosch, Zea Books, 2017, ss. 483-491.

Taft, Robert F. „The Decline of Communion in Byzantium and the Dis tancing of the Congregation from the Liturgical Action: Cause, Effect, or Neither?". Thresholds of the Sacred: Architectural, Art Historical, Liturgical, and Theological Perspectives on Religious Screens, East and West, red. Sharon E.J. Gerstel, Dumbarton Oaks Research Library and Collection Washington DC, 2006, ss. 27-52.

Thébert, Yvon. "Private life and domestic architecture in Roman Africa"'. A History of Private Life, red. Paul Veyne, Harvard University Press, 1992, ss. 313-409.

Thomas, Thelma K., "Material Meaning in Late Antiquity". Designing Identinty: the power of textiles in Late Antiquity, red. Thelma K. Thomas, Princeton University Press, 2016, ss. 20-53.

Williamson, Christina G. "Filters of Light. Greek temple doorways as portals of epiphanies". Sacred Thresholds: The Door to the Sanctuary in Late Antiquity, red. Emilie van Opstall i Sible de Blaauw, Brill, 2018, ss. 309-340. 


\section{ZASŁONY W KOŚCIOŁACH WCZESNOCHRZEŚCIJAŃSKICH W IV-VI WIEKU - ZARYS PROBLEMATYKI \\ Streszczenie}

Jednym z nieodłącznych elementów wyposażenia kościołów wczesnochrześcijańskich były różnego rodzaju tkaniny, wśród których szczególne miejsce, ze względu na ich szerokie zastosowanie i wielorakie funkcje, zajmowały zasłony. Umieszczane w drzwiach wejściowych, w przegrodach chórowych, w cyborium nad ołtarzem, w absydzie, pomiędzy nawami, zasłony pełniły funkcje praktyczne, symboliczne i dekoracyjne. Celem niniejszego artykułu jest zarysowanie problematyki związanej ze stosowaniem zasłon w kościołach wczesnochrześcijańskich.

Słowa kluczowe: tkaniny późnoantyczne; zasłony; wczesnochrześcijańskie kościoły; poikilia.

\section{VEILS IN EARLY CHRISTIAN CHURCHES \\ IN THE $4^{\mathrm{TH}}-6^{\mathrm{TH}}$ CENTURIES: \\ AN OUTLINE}

S u m m a r y

An inherent element of the furnishings of early Christian churches was various types of fabrics, among which, due to their wide application and high functionality, veils had a special significance. Hung in entrance doors, in choir barriers, in the ciborium above the altar, in the apse, between the naves, veils had practical, symbolic and decorative functions. This article aims to outline issues related to the use of veils in early Christian churches.

Keywords: Late Antique fabrics; curtains; early Christian churches; poikilia. 


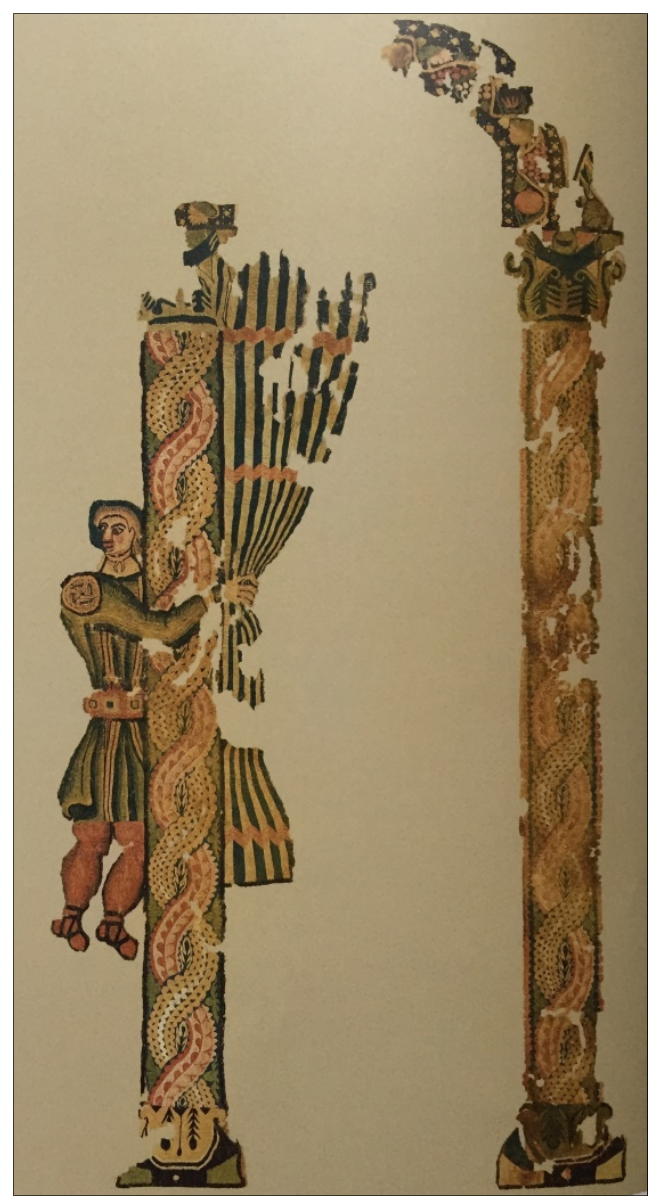

1. Fragment tkaniny ściennej z przedstawieniem ostiariusza, prawdopodobnie z Egiptu, V wiek,

Museum of Fine Arts, Boston, za: de Moor i Fluck, fig. 4 


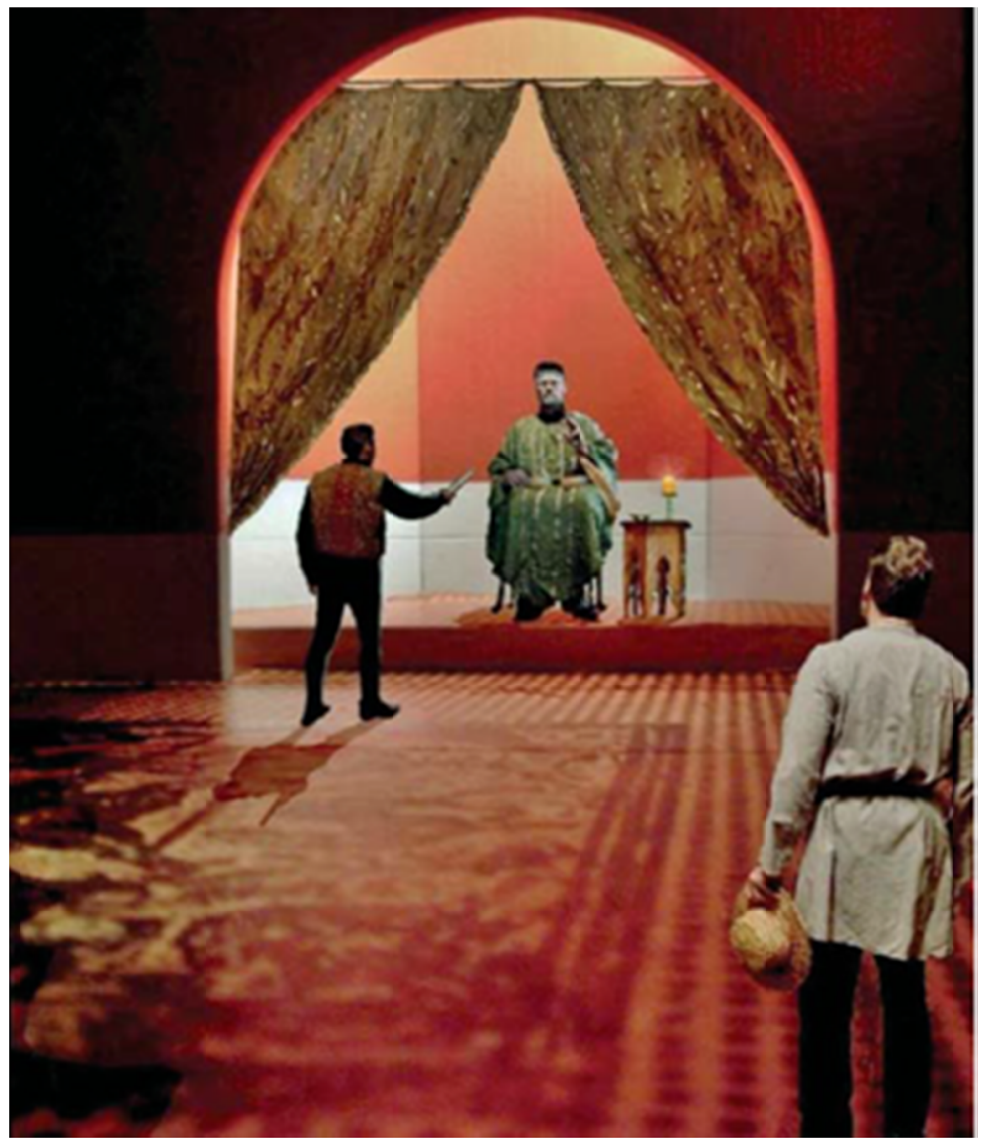

2. Rekonstrukcja prywatnej bazyliki w Willi Maternusa w Carranque (Toledo), IV wiek, za: Stephenson, fig. 10 


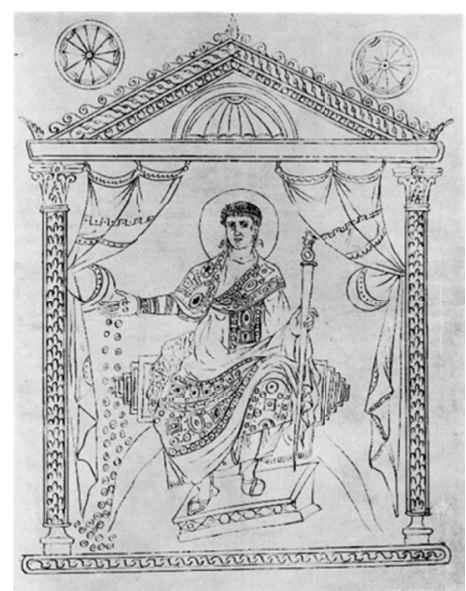

3. Wyobrażenie Konstancjusza II w Chronografie z 354 r., en.wikipedia.org/wiki/Chronograph_of_354\#/media/File:

07_constantius2Chrono354.png. Dostęp 8.10.2020

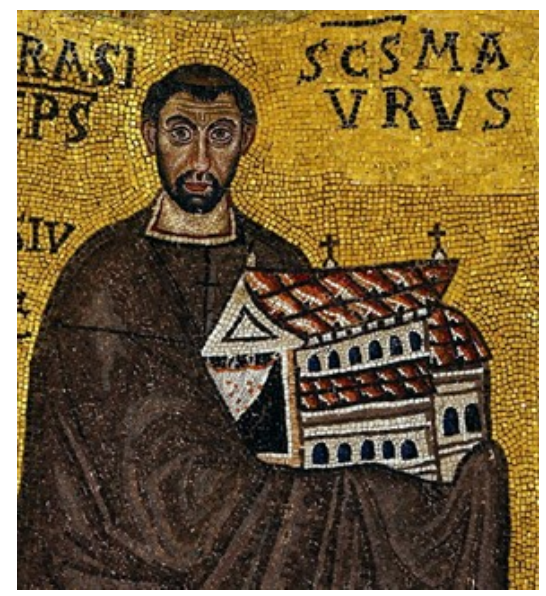

4. Mozaika w tzw. bazylice eufrazjańskiej w Poreč, VI wiek, commons.wikimedia.org/wiki/File:Bishop_Euphrasius.jpg. Dostęp 8.10.2020 


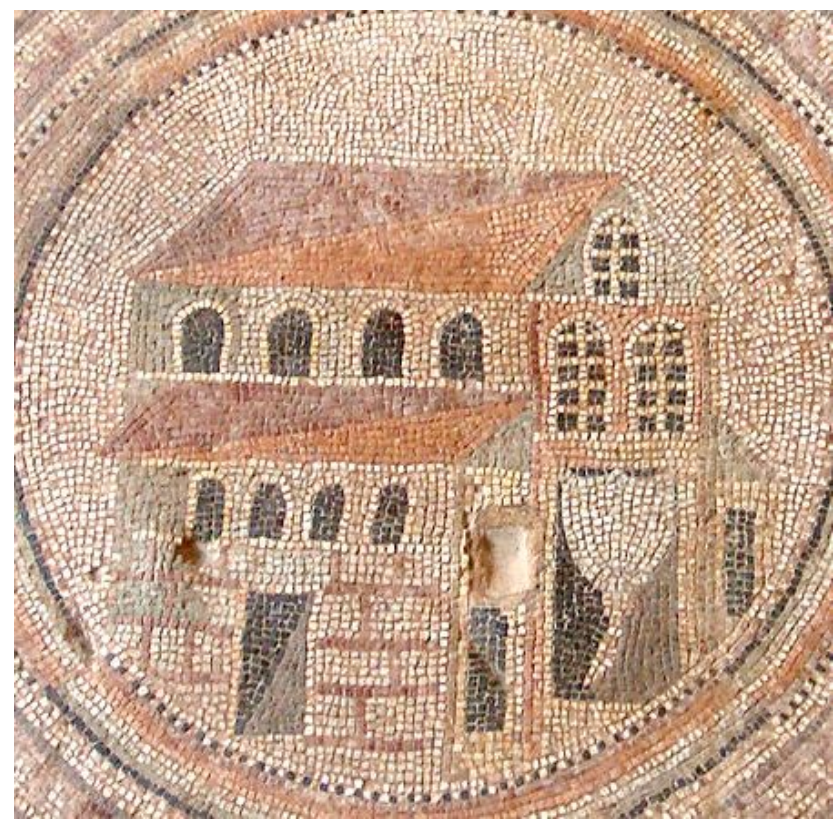

5. Mozaika w Taybat al-Imam, ok. 442 r.,

en.wikipedia.org/wiki/Taybat_al-Imam\#/media/File:

Mosaic_Taybat_Al_Imam_detail.jpg. Dostęp 8.10.2020

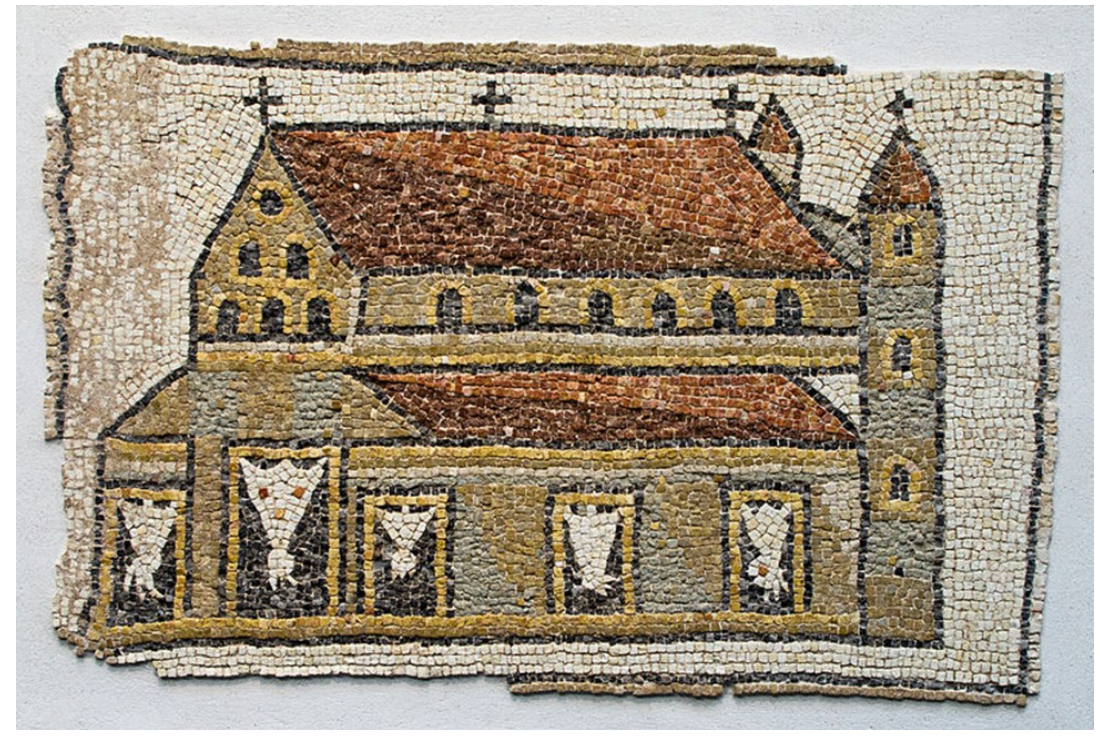

6. Mozaika ze wschodnich regionów Morza Śródziemnego w Luwrze, commons.wikimedia.org/wiki/File:Basilique_\%C3\%A0_tours__mosa\%C3\%AFque_Louvre.jpg. Dostęp 8.10.2020 


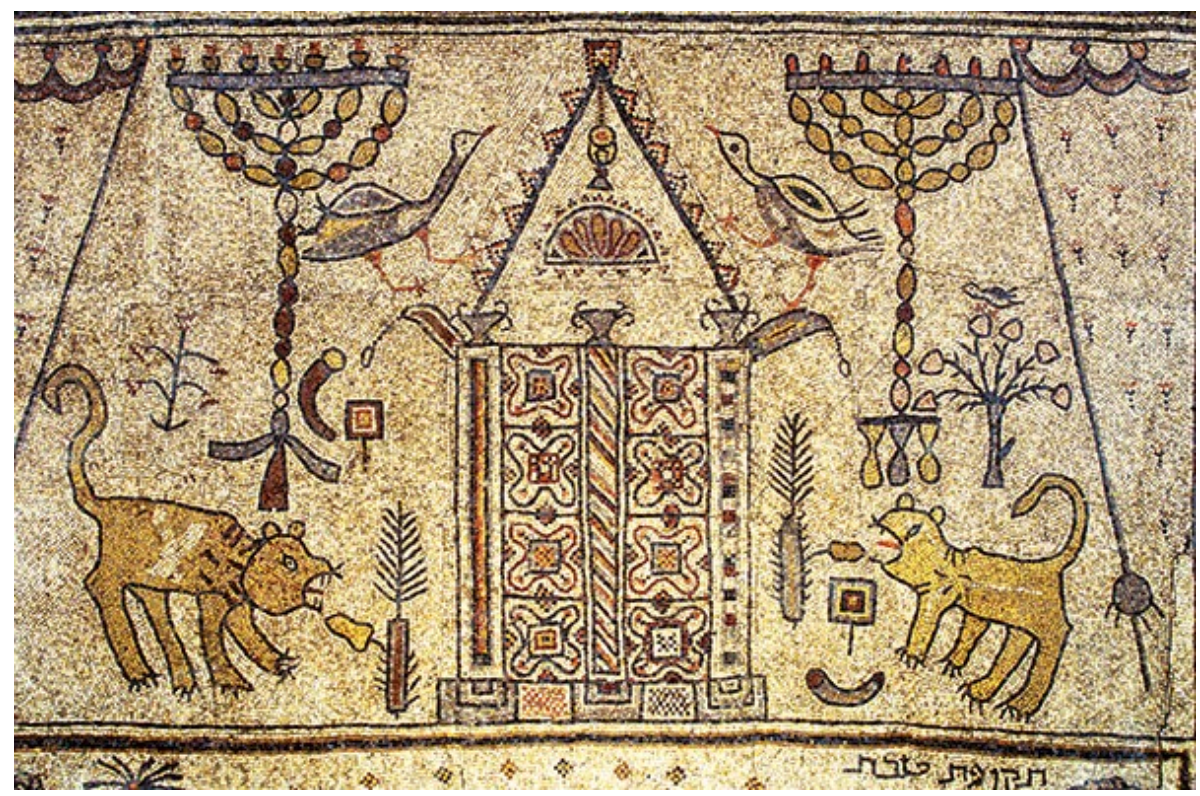

7. Mozaika z synagogi w Beth Alpha, VI wiek za: Rosenthal-Heigenbottom, fig. 6

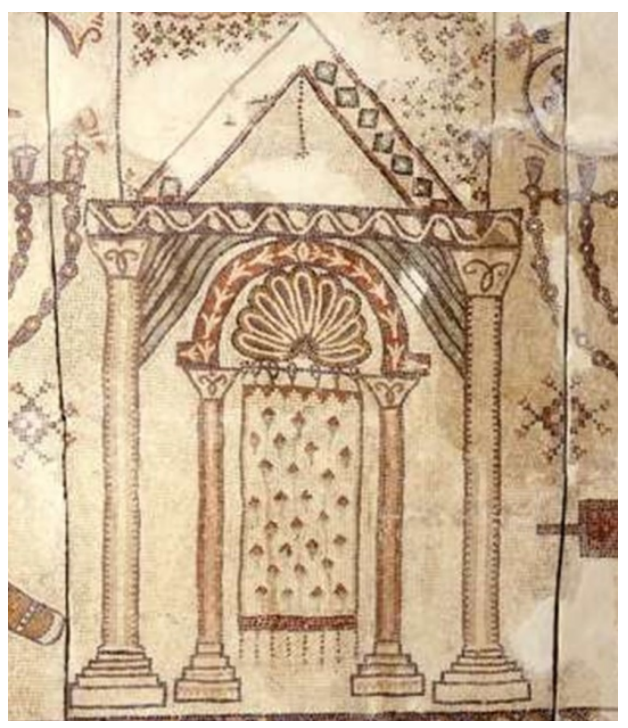

8. Mozaika z synagogi w Beth Shean, VI wiek, za: Rosenthal-Heigenbottom, fig. 9 


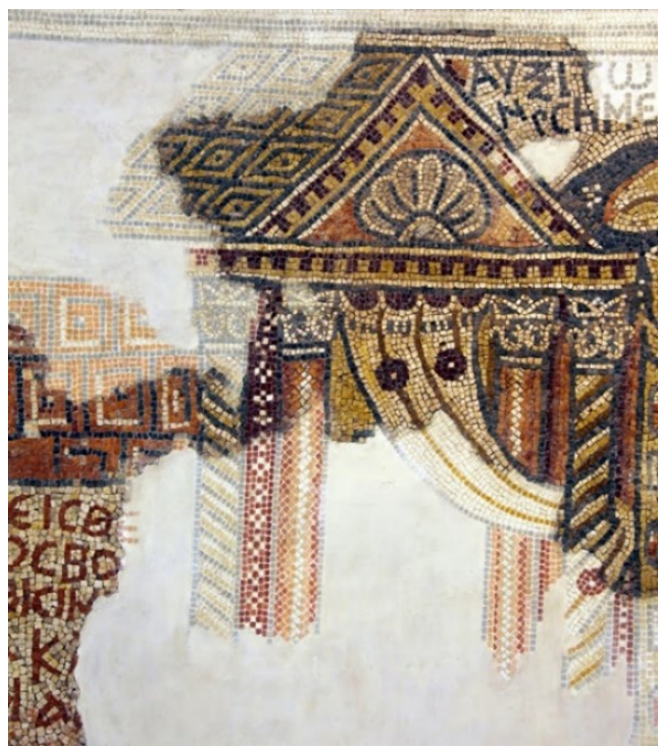

9. Mozaika z synagogi w El-Khirbe, VI wiek, hamblinofjerusalem.blogspot.com/2010/01/

temple-mosaics-from-el-khirbe-synagogue.html. Dostęp 8.10.2020

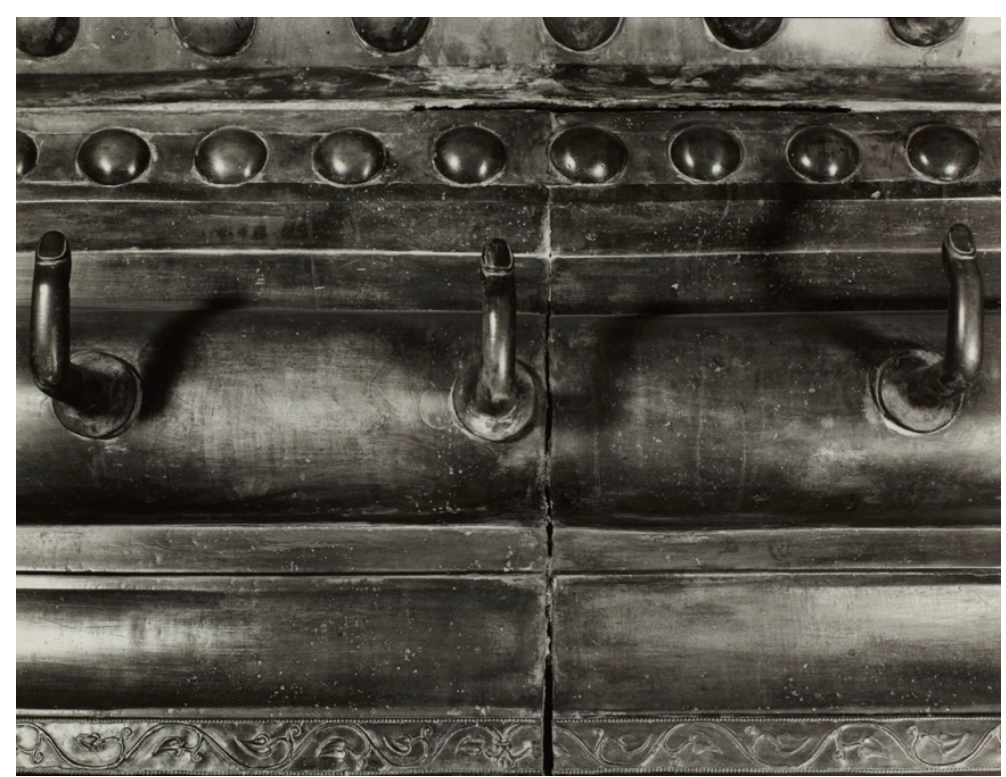

10. Haki nad drzwiami Hagia Sophia w Konstantynopolu, poł. VI wieku za: Maguire, fig. 7b, www.doaks.org/resources/textiles/essays/maguire. Dostęp 8.10.2020 


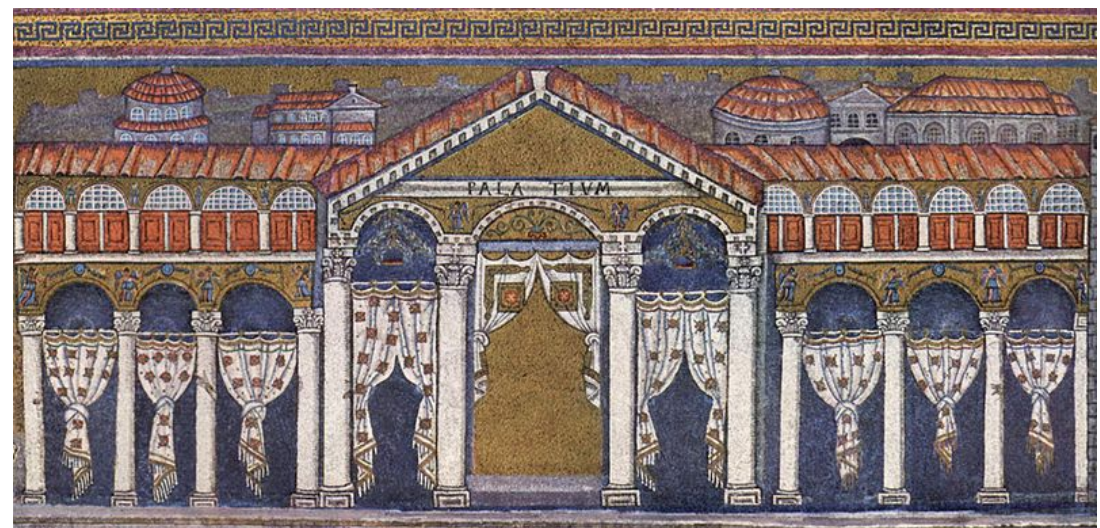

11. Wyobrażenie „palatium” w San Apollinare Nuovo w Ravennie, ok. 526 r., commons.wikimedia.org/wiki/File:Meister_von_San_Apollinare_Nuovo_in_Ravenna_003.jpg. Dostęp 8.10.2020

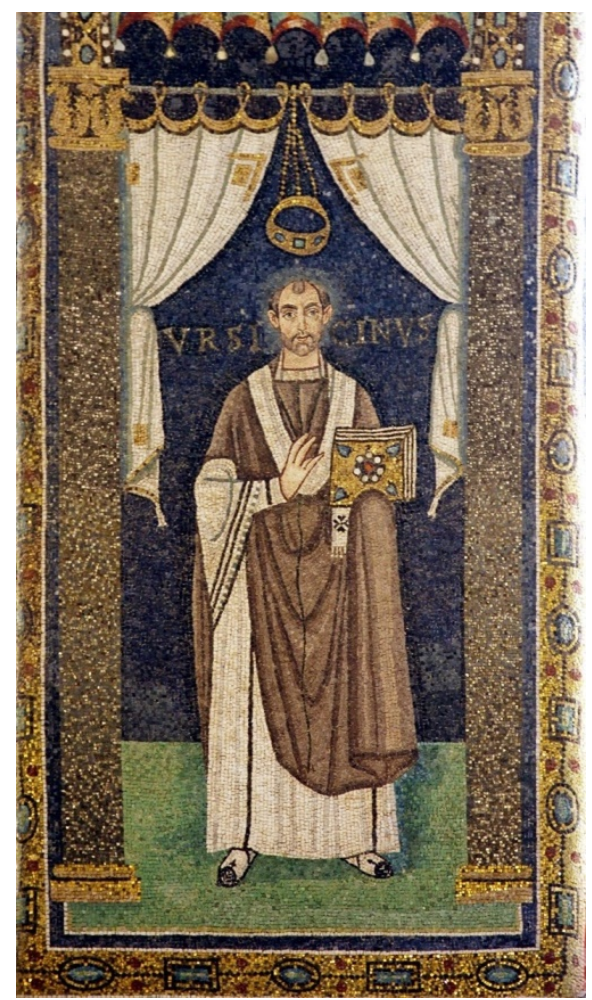

12. Mozaika w San Apollinare in Classe, ok. 549 r., en.wikipedia.org/wiki/Ursicinus_(Bishop_of_Ravenna)\#/media/File: Saint_Ursicinus_of_Ravenna_mosaic_(crop)_-_Sant'Apollinare_in_Classe_ -_Ravenna_2016.jpg. Dostęp 8.10.2020 


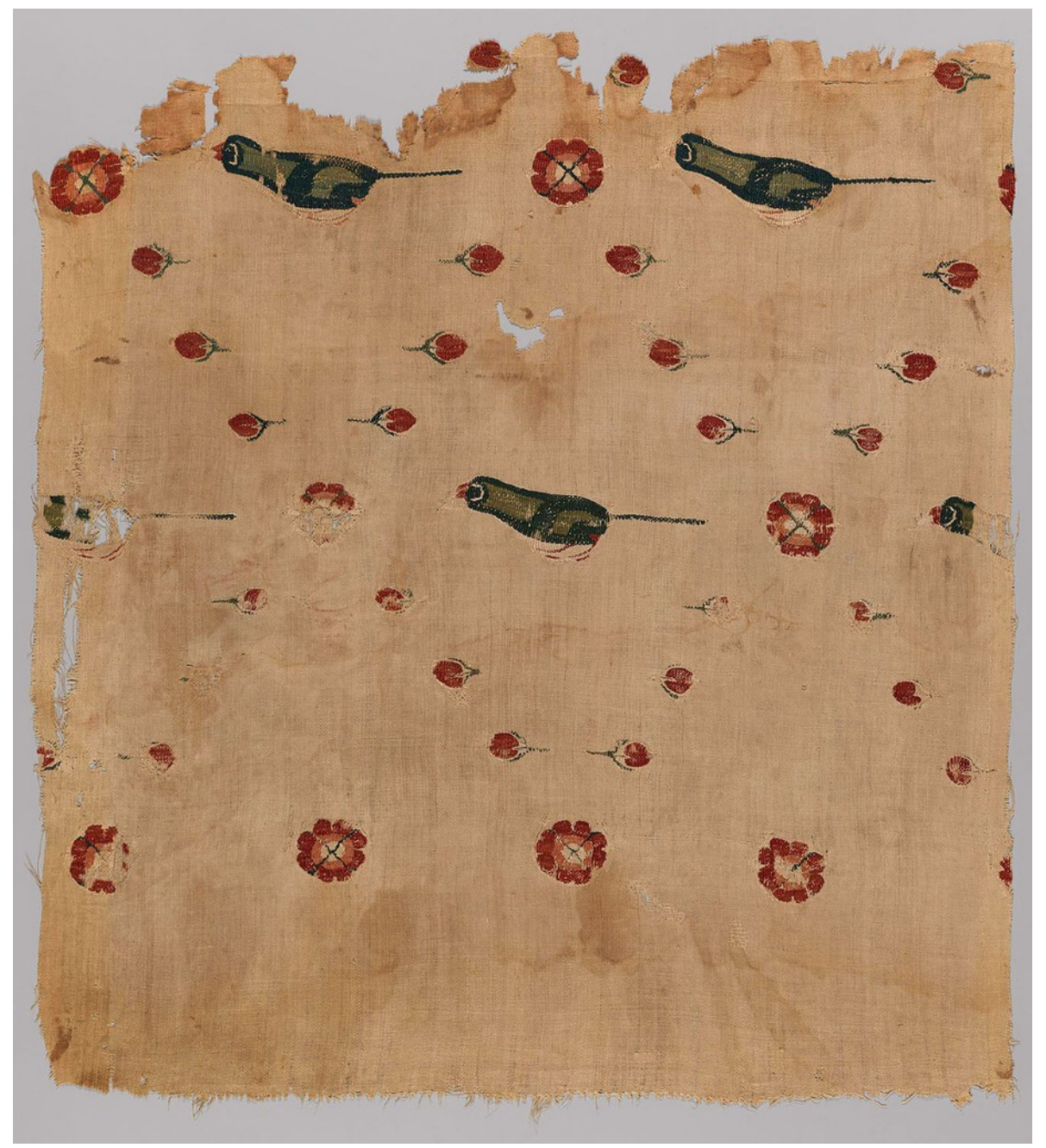

13. Fragment zasłony (lub tkaniny ściennej), V-VIII wiek, Metropolitan Museum of Art, New York,

www.metmuseum.org/art/collection/search/444323. Dostęp 8.10.2020 